SUSTAINABLE FORESTRY

COLLECTION 71-72, 2015
ODRŽIVO ŠUMARSTVO

ZBORNIK RADOVA 71-72, 2015

UDK 630*1:502.175(497.11)“2015“=111

Original scientific paper

\title{
AIR POLLUTION IMPACT ASSESSMENT AND MONITORING, ITS EFFECTS ON THE FOREST ECOSYSTEMS IN THE TERRITORY OF THE REPUBLIC OF SERBIA IN 2015
}

\author{
Renata GAGIĆ SERDAR ${ }^{l}$, Tomislav STEFANOVIĆ ${ }^{l}$, Goran ČEŠLJAR ${ }^{l}$, Svetlana \\ BILIBAJKIĆ ${ }^{l}$, Radovan NEVENIĆ ${ }^{l}$, Ilija ĐORĐEVIĆ ${ }^{l}$, Zoran PODUŠKA ${ }^{l}$
}

\begin{abstract}
In 2015 research observations of permanent monitoring of forests in the Republic of Serbia on permanent experimental plots were carried out in accordance with the Instructions of the International Cooperative Programme on Forest Condition Monitoring and data were collected for the necessary analyses. Experimental fields (FSP) are systematically arranged in $16 \times 16 \mathrm{~km}$ or $4 \times 4 \mathrm{~km}$ grid systems. Basic parameters evaluated in the plots were: presence of pests, phytopahtological changes, as well as of other types and causes of forest damage. The aim of this paper was to correlate these factors that affect the vitality of forests and analyses of adverse influences affecting the forest ecosystems, the degree of defoliation and color changes (chlorosis on forest vegetation), and above all, the extent of damage to forests in Serbia in 2015.
\end{abstract}

Key words: Integrated Pest Management, Defoliation, ICP Forest Sample Plots, Crown Condition Monitoring, Serbia

\section{INTRODUCTION}

Forest ecosystems form the basis of a healthy environment and are key factors for its preservation and improvement. Forests and forest areas provide numerous generally beneficial functionalities that are not related to the production of wood as the main forest produce. Serbia is a country with a multitude of diverse

\footnotetext{
${ }^{1}$ Institute of Forestry, Kneza Višeslava 3, 11030 Belgrade, Serbia
} 
living species and is literally more than rich in biodiversity, which is primarily found in forest ecosystems.

Forest ecosystems are exposed to both abiotic and biotic impacts the synergy of which maintains the ecosystem balance. In addition to the favorable effects, the adverse influence of harmful abiotic and biotic factors cannot be ignored as they result in diminished vitality of individual trees, forest stands and ultimately the forest ecosystem (Marković, M., Rajković, S. and Nevenić, R., 2014).

In view of the aforesaid, Serbia has recognized significance of forest health monitoring and monitoring of the harmful abiotic and biotic factors impact on forests.

From 2013 up to 2015130 sample plots were defined and set up in the territory of the Republic of Serbia, arranged in $16 \times 16 \mathrm{~km}$ or $4 \times 4 \mathrm{~km}$ grid systems (Nevenić et al., 2006). In 2015 forest species condition was assessed at all 130 sample plots in Serbia. Defoliation and discoloration assessment and monitoring of damages caused by both biotic and abiotic factors were conducted on the total of 2,910 trees. Such continuous large-scale or appropriate-scale monitoring may warn of forest damage, caused by both biotic and abiotic factors.

Biomonitoring is based on the dense network of permanent experimental sites, called sample plots, where every vegetation season health and vitality of individual pre-sampled trees are assessed (Nevenić et al., 2011).

\section{METHOD AND CRITERIA}

Visual field observations were made at sample plots in the territory of the Republic of Serbia in accordance with the ICP Forests Manual ${ }^{2}$ as follows: assessment of the crown condition and identification of damage on trees caused by diseases and pests. ICP Forests Manual prescribes that the crown condition be assessed at all sample plots each year and that the soli condition and nutrition of forest trees - foliar analyses - be assessed every 10 years.

Based on the coordinate grid of sample plots, a sample plot is established and designated with the bright colored metal stick placed in the middle of the plot. Tree samples for crown condition assessment are systematically selected in clusters of 4 sites. In each of the cardinal directions, at a distance of $25 \mathrm{~m}$ from the central point (the metal stick), the nearest six trees are selected (the total of 24 trees) and defined as the assessment sample. The sampled trees include all tree species provided their height is over $60 \mathrm{~cm}$. Crown classes according to $\mathrm{Kraft}^{3}$ (predominant, codominant, intermediate, suppressed, dying) determine the trees considered for assessment, yet these trees ought to be without significant mechanical damage. The selected trees are permanently bark-marked with numbers for future assessment purposes. Trees removed due to undertaken forest management measures or for other reasons are replaced with new selected trees. If

\footnotetext{
${ }^{2}$ Manual - rules of procedure http://www.icp-forests.org/Manual.htm

${ }^{3}$ Modified concept of forest tree crown classification, traditional measurement of variables used in forestry, initially implemented in Germany in the 19th century, Kraft (1884)
} 
a stand is removed by cutting only, the central point is left until a new stand is formed (Nevenić et al, 2008).

Within national and international research (Level I), crown condition is expressed in terms of defoliation classes, discoloration and combined damage classes. Defoliation is assessed in 5\% intervals and grouped in 5 classes of uneven ranges (Table 1). Foliage discoloration is a significant diagnostic indicator of the crown condition and may be assessed according to the classes provided in Table 2. The combined damage class is presented in Table 3.

Table 1. Defoliation classes as per UN/ECE $E^{4}$ and $E U^{5}$ classification

\begin{tabular}{|c|c|c|}
\hline Defoliation - drying - class & Defoliation extent & Foliage loss (\%) \\
\hline 0 & None & $0-10$ \\
\hline 1 & Slight & $10-25$ \\
\hline 2 & Moderate & $25-60$ \\
\hline 3 & Severe & $60-100$ \\
\hline 4 & Dead & 100 \\
\hline
\end{tabular}

Table 2. Discoloration classes as per UN/ECE and EU classification

\begin{tabular}{|c|c|c|}
\hline Discoloration -chlorosis - class & Discoloration extent & Share of the foliage chlorosis (\%) \\
\hline 0 & None & $0-10$ \\
\hline 1 & Slight & $10-25$ \\
\hline 2 & Moderate & $25-60$ \\
\hline 3 & Severe & $60-100$ \\
\hline 4 & Dead & 100 \\
\hline
\end{tabular}

Table 3. Combined damage assessment

\begin{tabular}{|c|c|c|c|c|}
\hline $\begin{array}{c}\text { Defoliation-drying- } \\
\text { class }\end{array}$ & \multicolumn{4}{|c|}{ Discoloration - chlorosis- class } \\
\hline \multirow{3}{*}{0} & 0 & 1 & 2 & 3 \\
\cline { 2 - 5 } & \multicolumn{4}{|c|}{ Damage class results } \\
\cline { 2 - 5 } & 0 & 0 & 2 & 2 \\
\hline 1 & 0 & 1 & 3 & 3 \\
\hline 2 & 1 & 2 & 3 & 3 \\
\hline 3 & 2 & 3 & & 2 \\
\hline
\end{tabular}

Combined assessment of defoliation, discoloration and damage is presented in Table 3 above, where causal relations of the three mutually dependent factors are shown. For example, in instances of non-existent defoliation (drying) and discoloration value of 1 , it was not possible to identify significant damage on trees (0), whereas severe defoliation (3) and severe chlorosis (3) were indicative of the existence of acute damage designated with number 3 .

In addition, phonological monitoring of visible developments in the life cycle of plants as per methodological approach yields parameters that contribute to the establishment of phenomena in forest ecosystems. Information on the timing and duration of certain developments in plants provide valuable data on their condition as well as on potential impact of the environment on the plants, such as the impact of climate fluctuations (ICP Forests Manual, 2010).

\footnotetext{
${ }^{4}$ United Nations Economic Commission for Europe

${ }^{5}$ European Union
} 
At each Level II sample plot 15 trees of the predominant species were selected for phonological observations, where the following parameters were detected and monitored: foliation, discoloration of leaves/conifer needles, defoliation, significant indicators of damage in leaves/conifer needles or crowns, other damages (branch and trunk breakage and trunk uprooting) and secondary budding and blooming.

\section{EVENT: $\quad$ 1. foliation; 2. discoloration; 3. defoliation; 4. foliage damage; \\ 5. other damages; 6 . water sprouts; 7 . blooming}

EVENT REGISTRATION - FOLIATION, DEFOLIATION AND BLOOMING:

$1-<1 \% ; 2-1-33 \% ; 3-33-66 \% ; 4-66-99 \% ; 5->99 \%$

\section{BLOOMING AND DAMAGES:}

6 - absence; 7 - presence; 7.1 - rare; 7.2 - moderate;

7.3 - thick, severe

The above listed parameters were monitored in trees situated in the sample plot and for the entire plot in general, as from the first field visit.

Long-term observation of phonological developments and interpretation of the results obtained using the method of time series analysis enable identifying patterns of deviation from the usual. At the level of significant shift in phenological phenomena (blooming or fruit maturing seasons, etc.) elements of global climate changes are recognized.

By processing data obtained using the most contemporary technological approach in phenological monitoring (placement of devices for recording or taking photographs) predictive models are arrived at for even clearer estimates.

\section{RESULTS}

At most common tree species at Level 1 sample plots causes of damage were recognized, determined (designated with scientific names) and associated with damages in certain number-designated sample plots across Serbia.

This so-called overall status in 2015 comprised:

Field work $\rightarrow$ Tree species $\rightarrow$ Sample plot name and number $\rightarrow$ cause of damage $\rightarrow$ Damage or disease occurred $\rightarrow$ Damage or disease progress or assessment through the use of standard parameters $\rightarrow$ final result of "monitoring" per experimental field $\rightarrow 2015$ results presented in this paper are shown in Tables 4 and 5 .

Table 4 highlights the agent and sample plot number, while Table 5 presents the share (percentage, \%) in the total number of trees at all 130 sample plots in the fields established for this purpose (soil chemistry analyses were also conducted and those of foliar chemism features).

All of this represents an elaborate set of tasks with a tendency for improvement year on year as well as a more detailed and more comprehensive reporting system - identical operations are synchronized on the local level and in the region. Everything is focused on the general objective - monitoring is becoming a prediction mechanism for estimating risk and localizing critical problems of forest drying and instrument of the current applicable integral 
approach in forest protection. For each sample plot the cause of damage or disease of the affected tree is stated per tree species. The tables include the most common species (most present in Level I experimental fields in the territory of the Republic of Serbia excluding the territory of AP of Vojvodina in 2015) in the territory with plot grids (16 x 16 and $4 \times 4 \mathrm{~km})$.

At Level I sample lots the predominant tree species is beech. In 2015 vitality of beech forests was acutely endangered primarily by insect defoliators. As in prior years, in 2015 a mild attack by gall midges and leaf-miners was identified on foliage.

These are Mikiola fagi (Htg.), beech gall midge, which form galls on beech leaves (which are then deformed). FE Leskovac and FE Ivanjica are specific in this respect as their huge areas were attacked and beech trees were in severe jeopardy from innumerate mines on assimilation leaf surfaces. The situation was the same in 2014. Such heavy infestation will certainly affect the growth and the overall condition of beech trees and their resistance to other pathogens. Deformed and covered leaves will have severely harmed vitality of beech forests for the upcoming period as well, until the midge population becomes stable or reduced by parasitoids. In addition, leaf-miners such as Hartigola annulipes Hartig and Phyllonorycter messaniella Zell (Figure 2) were also observed. Beech leaf-miners (Lepidoptera. Gracillaridae) proved to be the most common pests affecting the sample beech trees, as demonstrated by the results of observations at sample plots in the same regions of Serbia in 2015, for plots 76, 77 and 78 in particular.

Leaf-miner Rhynchaenus fagi L. (Syn. Orchestes fagi L.) - beech leafmining weevil - was identified at several sample plots, where in a number of beech trees attacks recorded ranged from mild to severe. From the Cecidomyidae family of gall midges, Dryomia circinnans Girauld species is frequently found on the back of leaves of both beech and oak trees at sample plots. These galls resemble the above mentioned species except that they are covered with fine hair. They are equally harmful as they cause physiological disorder in leaves and young plants stagnate due to general deformity.

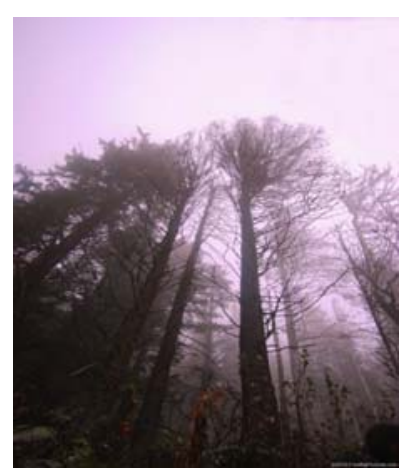

Figure 1. Sample plots 428, 429: fir trees, completely dry and broken (original photo of the Author)

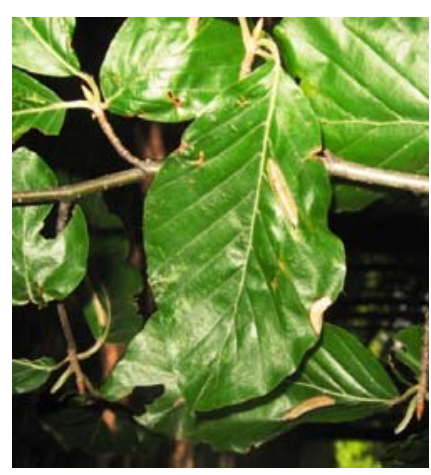

Figure 2. Sample plot 32: Beech leafminer (Lepidoptera. Gracillaridae)(original photo of the Author) 
Table 4. Damage causes, host plant tree species

\begin{tabular}{|c|c|c|c|c|c|c|}
\hline $\begin{array}{c}\text { Damage / Tree } \\
\text { species / } \\
\text { Sample plot / } \\
\text { Cause }\end{array}$ & $\begin{array}{c}\text { Insects } \\
\text { defoliators, } \\
\text { chewers, leaf- } \\
\text { miners, gall } \\
\text { midges, leaf- } \\
\text { rollers and bark } \\
\text { beetles /sample } \\
\text { plot number }\end{array}$ & $\begin{array}{c}\text { Fungi } \\
\text { bark canker, } \\
\text { wounds, stem rot, } \\
\text { spots, freckles, } \\
\text { carpophores, root } \\
\text { rot, complete } \\
\text { drying / sample } \\
\text { plot number }\end{array}$ & $\begin{array}{c}\text { Abiotic agents } \\
\text { ice ruptures, } \\
\text { frost cracks, } \\
\text { bark cracks, } \\
\text { drought /sample } \\
\text { plot number }\end{array}$ & $\begin{array}{c}\text { Man-made } \\
\text { mechanical } \\
\text { damage from } \\
\text { pullout force } \\
\text { (bark stripped } \\
\text { off, breakage, } \\
\text { various injuries) } \\
\text { /sample plot } \\
\text { number }\end{array}$ & $\begin{array}{c}\text { Forest fires } \\
\text { / sample plot } \\
\text { number }\end{array}$ & $\begin{array}{c}\text { Other } \\
\text { causes / } \\
\text { sample } \\
\text { plot } \\
\text { number }\end{array}$ \\
\hline Beech & Leaf-miners / 32 & $\begin{array}{c}\text { Several causes } \\
\text { combined /9, 13, } \\
50,52,55,58,85 \\
91,98,99,87 \\
407,412\end{array}$ & $\begin{array}{l}\text { Ice ruptures, } \\
\text { frost cracks / } \\
412, \sum 7 \text { trees, } \\
413 \sum 15 \text { trees }\end{array}$ & $\begin{array}{c}\text { Mechanical } \\
\text { injury / 4, 50; } \\
\text { severe } \\
\text { mechanical } \\
\text { injury / 51, } 69 \text {, } \\
90\end{array}$ & $\begin{array}{c}10 \text { severely } \\
\text { damaged } \\
\text { trees / } 96 \text { (as } \\
\text { well as } \\
\text { C.sativa) }\end{array}$ & \\
\hline Hornbeam & & Central rot / 55 & & & & \\
\hline Turkey oak & $\begin{array}{c}\text { Leaf miners /29, } \\
34,36 ; \\
\text { Altica } \\
\text { quercetorum / } 39 \\
\end{array}$ & & $\begin{array}{c}\text { Several causes } \\
\text { combined/ } \\
6,70,92\end{array}$ & & & $\begin{array}{l}\text { Bulge } / 30 \\
\text { Bacterial } \\
\text { tumor } / 38\end{array}$ \\
\hline Hungarian oak & $\begin{array}{c}\text { (Torticidae) / 2, } \\
17,2029,39 \\
\text { and } 88\end{array}$ & $\begin{array}{c}\text { Microsphaera } \\
\text { maculiformis / 17, } \\
20\end{array}$ & $\begin{array}{c}\text { Frost ribs / 17, } \\
20\end{array}$ & & & $\begin{array}{l}\text { V.album; } \\
\text { L.europeus } \\
\quad / 60\end{array}$ \\
\hline Sessile oak & $\begin{array}{c}\text { Leaf-miners / } 75 \text {, } \\
77\end{array}$ & $\begin{array}{c}\text { Microsphaera } \\
\text { alphitoides / } 107\end{array}$ & $\begin{array}{c}\text { Severe drought / } \\
78\end{array}$ & & & \\
\hline Fir & & $\begin{array}{c}\text { Armillaria ostoyae } \\
\quad / 415,418\end{array}$ & $\begin{array}{c}\text { Severe drought / } \\
428,429\end{array}$ & $\begin{array}{c}\text { Mechanical } \\
\text { pullout injury / } \\
401,402\end{array}$ & & \\
\hline Spruce & $\begin{array}{c}\text { Bark beetles / } \\
73,74\end{array}$ & $\begin{array}{c}\text { Heterobasidion } \\
\text { annosum / } 419\end{array}$ & & $\begin{array}{c}\text { Mechanical } \\
\text { pullout injury / } \\
406 \\
\end{array}$ & & \\
\hline Austrian pine & $\begin{array}{c}\text { Bark beetles / } \\
419\end{array}$ & $\begin{array}{l}\text { Dotistroma pini; } \\
\text { Diprion pini / } 65\end{array}$ & & & & \\
\hline Black locust & $\begin{array}{c}\text { Gall midges, } \\
\text { leaf-miners / } 428\end{array}$ & & & & & \\
\hline Scots pine & $\begin{array}{c}\text { Bark beetles / } \\
45,59\end{array}$ & $\begin{array}{c}\text { Lophodermium sp. } \\
\text { (both most } \\
\text { common species) / } \\
53\end{array}$ & & & & \\
\hline
\end{tabular}


Table 5. Damage causes per host plant tree species and sample plot number

\begin{tabular}{|c|c|c|c|c|c|c|c|c|c|}
\hline & $\begin{array}{l}\text { Defoliation } \\
(\%)\end{array}$ & Wildlife & Insects & Fungi & $\begin{array}{l}\text { Abiotic } \\
\text { agents }\end{array}$ & $\begin{array}{l}\text { Man- } \\
\text { made }\end{array}$ & Fire & $\begin{array}{c}\text { Local } \\
\text { pollution }\end{array}$ & $\begin{array}{c}\text { Other } \\
\text { damages }\end{array}$ \\
\hline All species & 11,48 & 0,00 & 8,04 & 5,50 & 3,33 & 0,62 & 0,24 & 0,00 & 4,19 \\
\hline All conifers & 12,78 & 0,00 & 0,30 & 9,47 & 2,66 & 0,30 & 0,00 & 0,00 & 8,58 \\
\hline Fir & 11,30 & 0,00 & 1,45 & 1,45 & 8,70 & 1,45 & 0,00 & 0,00 & 10,14 \\
\hline Spruce & 7,71 & 0,00 & 0,00 & 0,00 & 2,05 & 0,00 & 0,00 & 0,00 & 13,70 \\
\hline $\begin{array}{l}\text { Austrian } \\
\text { pine }\end{array}$ & 27,54 & 0,00 & 0,00 & 25,37 & 0,00 & 0,00 & 0,00 & 0,00 & 0,00 \\
\hline Scots pine & 10,14 & 0,00 & 0,00 & 25,00 & 0,00 & 0,00 & 0,00 & 0,00 & 3,57 \\
\hline $\begin{array}{l}\text { All } \\
\text { deciduous } \\
\text { trees }\end{array}$ & 11,31 & 0,00 & 9,06 & 4,98 & 3,42 & 0,66 & 0,27 & 0,00 & 3,62 \\
\hline Hornbeam & 7,13 & 0,00 & 0,00 & 2,63 & 0,00 & 0,00 & 0,00 & 0,00 & 6,14 \\
\hline Beech & 8,10 & 0,00 & 10,63 & 0,07 & 4,13 & 0,01 & 0,83 & 0,00 & 4,37 \\
\hline Turkey oak & 12,52 & 0,00 & 11,93 & 3,18 & 1,99 & 0,20 & 0,00 & 0,00 & 4,97 \\
\hline $\begin{array}{l}\text { Hungarian } \\
\text { oak }\end{array}$ & 8,41 & 0,00 & 11,58 & 2,11 & 1,84 & 0,53 & 0,00 & 0,00 & 2,37 \\
\hline Sessile oak & 13,31 & 0,00 & 5,43 & 4,35 & 1,63 & 0,00 & 0,00 & 0,00 & 2,72 \\
\hline
\end{tabular}

At sample plots with black locust as a dominant tree species a locust gall midge Obolodiplosis robiniae Hald. was identified. This is a species introduced in the region and it appears in massive numbers causing frequent and large-scale damages, as recorded at sample plots in 2015 (Figure 3).

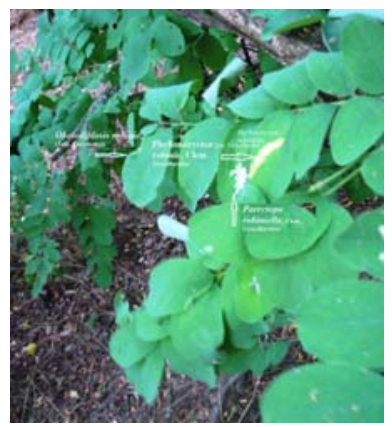

Figure 3. a) Black locust gall midge -

Obolodiplosis robiniae Hald. And locust leaf-miners b)Phyllonorycter robinie Clem.; c) Parectopa robiniella Clem. (original photo of the Author)

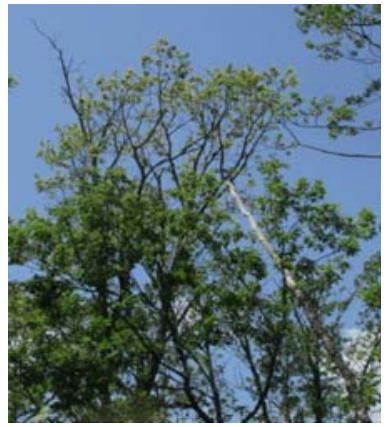

Figure 4. A tree typically affected by early oak defoliators (original photo of the Author)

To all oak as well as other deciduous forests, whether they be sprout forests or high forests, single-species or mixed-species, defoliators (insects from various families feeding on leaves) are particularly significant. Through their trophic attachment to oak leaves they cause partial or total defoliation (loss of foliage) 
(Figure 4), which in turn results in a series of adverse effects, physiological decline of the host plant, among others, i.e., creation of favorable conditions for action of a number of secondary harmful factors and can therefore be fatal to certain trees and entire stands (Nevenić et al., 2009).

Most common oaks found in forests within Level I sample plots are Sessile oak, Quercus petraea (Matt.) Lieblein, Turkey oak, Q. cerris L., and Hungarian oak, $Q$. frainetto Tenore. These trees are feeding plants for about 120 insect species most commonly from orders of Homoptera, Coleoptera, Diptera, Lepidoptera and Hymenoptera. These insects spend a part of their life or their certain development stages on various parts of trees and are trophically linked to trees. They chew leaf assimilation tissues, leaf buds and flower buds, young sprouts and twigs, or suck on the plant saps, can be xylophages or form galls where their larvae grow.

Only $10 \%$ of these species are forestry pests from the economic viewpoint as their oversized populations can heavily affect health and vitality of trees and considerably disbalance forest stands and cultures. Economically most significant among them is the gypsy moth - Lymantria dispar L. (Lepidoptera: Lymantriidae). The population numbers are measurable in many ways and each indicator of increase in gypsy moth numbers is among the highest forest management priorities. 2013 was the year of gypsy moth gradation in vast areas, primarily in the eastern region of Serbia. Since 2013 changes in oak stands specific for post-gradation period have been monitored - numbers of parasitoids, which are gypsy moth's natural enemies, and the reactions of trees that were severely affected (Češljar et al. 2013).

Early season oak defoliators are gradation-prone species, which, overporpagated for a few consecutive years, make physiologically weakened trees become prey to secondary pests. In case of trees stripped bare, tree growth is significantly reduced, there is no acorn production and the process of natural oak forest restoration is practically at a standstill. Such large-scale damages are most commonly caused by calamity species of oak leaf-roller moths and winter mothsgooseberries (Glavendekić M. and Medarević M., 2010).

Species most commonly detected at sites where in prior years severe infestations were recorded are: green oak leaf-roller - Tortrix viridana L., yellow oak leaf-roller - Aleimma loeflingiana L. (Lepidoptera: Tortricidae), gooseberries Colotois pennaria L., Agriopis spp., and winter moths - Erannis defoliaria L.. Alsophila spp. and Operophtera brumata L.

In a large number of Turkey oak trees Cynipidae were observed, particularly Neuroterus quercus baccarum species and Ticheria ekebladella L. leaf-miners. Sessile oak sprout forests in bad condition (sample plot 78) displayed in mature trees, crowns and young plants presence of oak powdery mildew Microsphaera alphitoides Grif.\& Maubl (sample plot 21) and Mycosphaerella maculiformis Mougou, A.; Dutech, C.; Desprez-Loustau, M. -L. (2008) pathogen. Of epixyl fungi there were wood rotting fungi on branches and severe central prism-shaped brown rot decay of the trunks. A small-scale presence of tumor-like shapes and rot in Turkey oak branches was identified. 


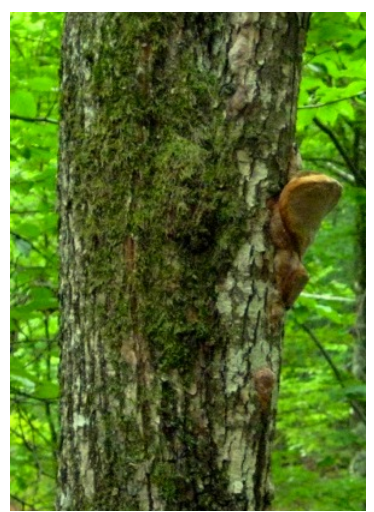

Figure 5. Sample plot 46: Phellinus igniarius L. ex Fr. on a Sessile oak (original photo of the Author)

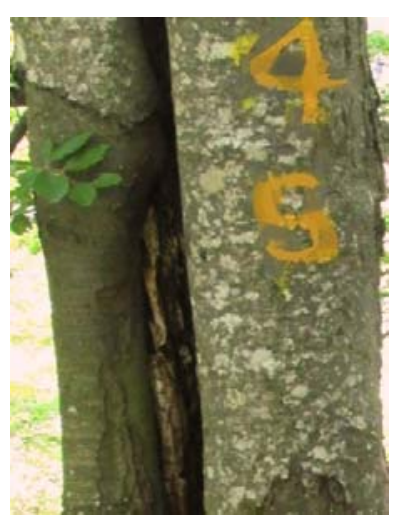

Figure 6. Central rot along a beech tree trunk (original photo of the Author)

Out of other biotic damage causes, in individual oak branches we detected the presence of parasitic flowering plants - white-berried mistletoe (Viscum album L.) and yellow misteltoe (Loranthus europaeus Jacq.), which cause physiological weakening of trees making them prone to attacks of hazardous pests ( Kinver, 2010). In Hungarian oak trees rotting fungi carpophores were detected - Coriolus versicolor (Fr.) Pil., Fomes annosus and central rot of different origins (Figure 7).

With regard to the beech forest disease causes, in individual trees the presence of carpophores or central rot along the entire trunk was detected, and tree litter showed plenty of carpophores of Fomes fomentarius (L.: Fr.), (Syn. Ungulina fomentaria / Linn. /Pat) Ungulina fomentaria. Beech tree trunks displayed central rot (Figures 5 and 6), canker wounds on the bark with recorded different development stages of Cryptoccocus fagisuga L. and several tree foot rotting. In the vicinity of sample plots with beech trees, there were a lot of rotten trees with carpophores of Trametes versicolor (Fr.) Pil. (Syn. Coriolus versicolor L. Et Fr.) Quel.). Nectria spp., was also frequently observed, recognized by its bright colored fruiting bodies (Karadžić, D. 2010).

Certain trees had severe injuries from tree cutting and pull-out, which are entryways for hazardous insect infestation and diseases (Nevenić et al., 2006).

Most common species in coniferous forests at sample plots are Austrian pine, Scots pine, spruce and fir trees. Following the 2015 assessment, one fifth of the total trees marked displayed visible injury caused by diseases (Figure 8) or pests. In spruce stands, there was a hazardous pathogen Chrysomyxa abietis (Wallr.) Unger on the needles (sample plots 419 and 420) but to a small extent, while in fir tree needles Cenangium ferruginosum Fr. (Syn. Cenangium abietis (Pegs.) Duby. and Lirula nervisequa (DC ex Fr.) Darker (Syn. Lophodermium nervisequim (DC ex Fr.) Rehm.) were detected. Completely dry and broken trees with lichens were also (Figure 1).

Scots pine needles were slightly infested with fungi Dothistroma pini Hulbary; (Syn. Scirrhia pini Funk et Parker) and Lophodermium pinastri, Lophodermium seditiosum as well as Cyclaneusma minus and Sclerophoma sp. and rotting fungus Fomitopsis pinicola (Fr.) P. Karst. (Taković- Tošić, M. et al 2014). 


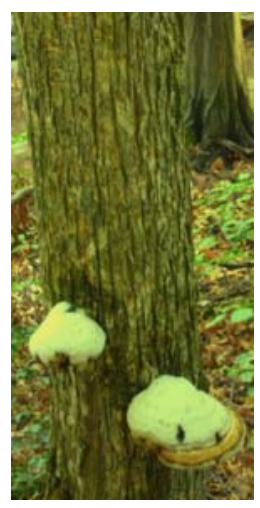

Figure 7. Sample plot 55: Carpophores of Fomes annosus and central rot (original photo of the Author)

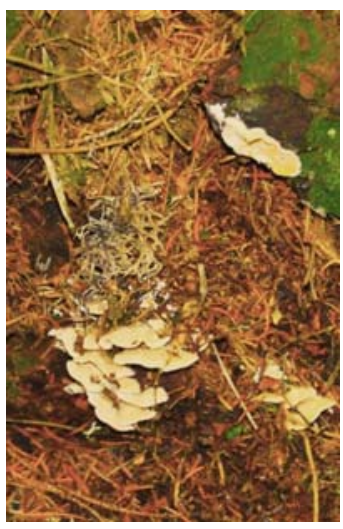

Figure 8. Sample plot 419: Carpophores of Heterobasidion annosum - the most hazardous pathogen of conifer forest at spruce tree foot; (original photo of the Author)

In 2015 Dothistroma pini slightly infested last year's Austrian pine needles. Scots pine needles showed presence of Diprion pini L., while in the bark there were fly-out openings of Siricidae and mechanical damages.

Ips typographus L. appears wherever there are dry uprooted spruce trees. In the root system it is then easy to observe the most hazardous pathogen of conifer tree stands - Heterobasidion annosum (Figure 8, sample plot 419).

Other deciduous species with recorded damages caused by diseases and pests are hornbeam, field maple, sycamore, raywood ash, birch and wild fruit trees. Ash weevil (Stereonychus fraxini Deg.) wasdtected in raywood ash trees at sample plot 11 .

Abiotic damages recorded included bulges of other than parasitic origin in the bark of individual beech trees. Frost cracks were clearly visible along the entire trunks. In 2015 there was no precipitation from the beginning of summer and in this rather dry year trees displayed yellow chlorotic crowns prematurely, as if the autumn drying commence das early as August, although the leaves remained on branches.

Beech trees at sample plot 7 showed damage and injury from tree cutting and pull-out. In this plot entire quadrants were missing, while some trees had injuries of unknown origin and about ten trees had bark inflammation (Chira, D., F. Chira, 1998). Mechanical damages caused by birds were detected in spruce trees at sample plot 420. Some Turkey oak trees suffered bark damage during tree marking. Man-made mechanical damages were identified in in about ten oak trees per sample plot, resulting from tree cutting and pull out. Such injuries pose a risk of entry of numerous hazardous insects and fungi, which can cause severe diseases. The share of such trees in the total number of trees assessed is $0.62 \%$.

Bulges of non-parasitic origin were detected in beech tree bark at sample plots 30 and 96 . Frost cracks stretched along the entire beech tree trunks. In one fir 
tree a lightning scar stretched along the entire trunk. Mechanical damages to sessile oak tree peaks were recorded in $4 \%$ of trees. Such damages occurred during tree cutting and pull-out. Frost cracks and other mechanical damages were present in Hungarian oak trees as well at 3 sample plots.

In a number of fir trees abundant sap secretion was observed and, according to the historical experience, all such trees are likely to dry the following year. A large-scale presence of lichen Usnea barbata, reflecting a healthy habitat, was perceived. There were also completely dry and broken trees fully covered with lichen (sample plots 415 and 416).

It is important to underline that in 2015 specific symptoms of an intense and widely spread phenomenon - ice ruptures - were clearly recognized and frequently observed in high, primarily beech forests. Such quantitatively and qualitatively severe injuries of trees occurred during dormancy in winter $2014 / 2015$, in periods of bitter frost preceded by precipitation or merely high humidity at certain altitudes of Homolje Mountain Range. Geographically, eastern parts of the country were most affected (sample plots in Eastern Serbia, exceptionally sample plot 70 - Lukovo, sample plot 35 - Jabukovac, and sample plot 412 - Tisovac). Sanitation must commence with sanitation tree cutting and further growth measures for a number of reasons. The injured trees are an easy prey for secondary pests and diseases. It is necessary to prevent them, i.e., to eliminate favorable conditions for incidence of possible pest calamities. Wherever an opening appeared, it is necessary to protect the exposed layers (risk of bark inflammation) and put an end as soon as possible to complex yet possible scenarios of cycles of linked and chained damages (an exemplary pattern of a beech stand decay after initial ice rupture as an abiotic factor is presented in Graph 1):

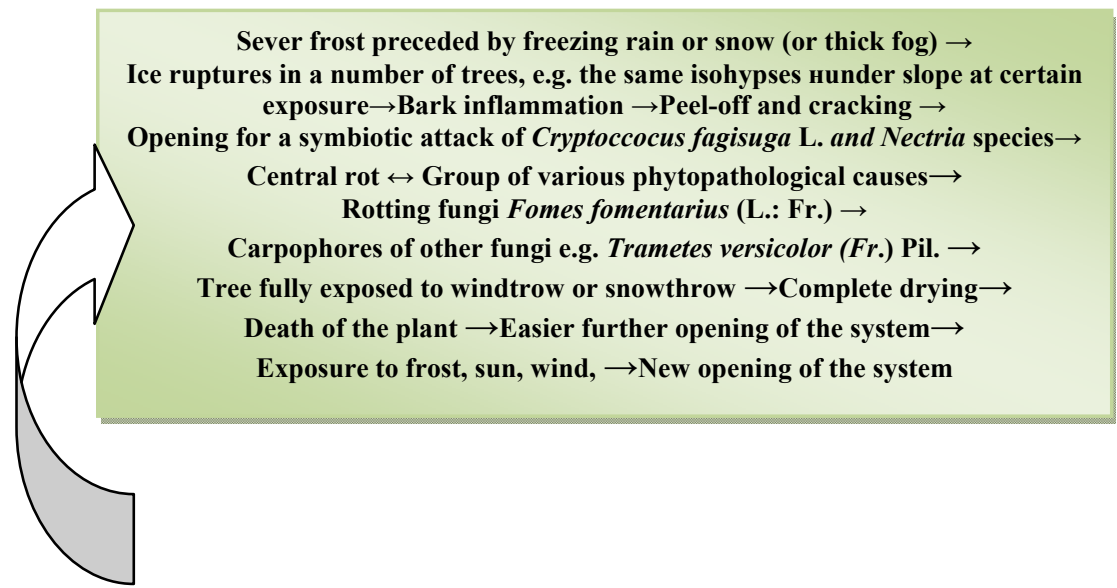

Graph 1: Example of the pattern of beech stand decay after the initial effect of a harmful agent (ice rupture) as an abiotic factor

In 2015 forest fires broke out $(0.24 \%$ trees affected) at several sample plots (e.g. sample plot 96), which resulted in total absence of assimilation organs in trees. Thereafter, the fire bed is occupied by pioneer vegetation, and more 
successful in succession are either invasive (blackberry) or economically and productively low graded species (birch, aspen, etc.).

At Level II sample plot Kopaonik 15 spruce trees (Picea abies L.) were selected for annual phenological observations. Phenophases were observed continuously, in succession. In the other two test fields, Mokra Gora and Crni Vrh, analyses were conducted using the same methodology.

Tables 6,7 and 8 provide details obtained by phonological observations at Level II sample plot Kopaonik, as from the first field visit.

Table 6. Table for registration of trees selected for intensive phenological monitoring - sample plot Kopaonik

\begin{tabular}{|c|c|c|c|c|c|c|c|c|}
\hline No. & Plot no. & $\begin{array}{c}\text { Species } \\
\text { code }\end{array}$ & $\begin{array}{c}\text { Placement } \\
\text { date }\end{array}$ & Tree no. & $\begin{array}{c}\text { Visible } \\
\text { crown } \\
\text { part }\end{array}$ & $\begin{array}{c}\text { Observation } \\
\text { direction }\end{array}$ & $\begin{array}{c}\text { Observation } \\
\text { position }\end{array}$ & $\begin{array}{c}\text { Other } \\
\text { observations }\end{array}$ \\
\hline 1 & 2 & 118 & 16.09 .10 & 75 & 3 & 4 & 1 & \\
\hline 2 & 2 & 118 & 16.09 .10 & 76 & 3 & 4 & 1 & \\
\hline 3 & 2 & 118 & 16.09 .10 & 78 & 3 & 4 & 1 & \\
\hline 4 & 2 & 118 & 16.09 .10 & 79 & 3 & 4 & 1 & \\
\hline 5 & 2 & 118 & 16.09 .10 & 80 & 3 & 4 & 1 & \\
\hline 6 & 2 & 118 & 16.09 .10 & 85 & 3 & 4 & 1 & \\
\hline 7 & 2 & 118 & 16.09 .10 & 86 & 3 & 4 & 1 & \\
\hline 8 & 2 & 118 & 16.09 .10 & 87 & 3 & 5 & 1 & \\
\hline 9 & 2 & 118 & 16.09 .10 & 88 & 2 & 6 & 1 & \\
\hline 10 & 2 & 118 & 16.09 .10 & 98 & 3 & 4 & 1 & \\
\hline 11 & 2 & 118 & 16.09 .10 & 114 & 2 & 6 & 1 & \\
\hline 12 & 2 & 118 & 16.09 .10 & 118 & 2 & 4 & 1 & \\
\hline 13 & 2 & 118 & 16.09 .10 & 120 & 1 & 7 & 1 & \\
\hline 14 & 2 & 118 & 16.09 .10 & 121 & 1 & 5 & 1 & \\
\hline 15 & 2 & 118 & 16.09 .10 & 124 & 2 & 8 & 1 & \\
\hline
\end{tabular}

Table 7. Phenological phenomena monitoring - sample plot Kopaonik

\begin{tabular}{|c|c|c|c|c|c|c|}
\hline No. & Plot no. & $\begin{array}{c}\text { Species } \\
\text { code }\end{array}$ & Event & $\begin{array}{c}\text { Observation } \\
\text { date }\end{array}$ & $\begin{array}{c}\text { Registered } \\
\text { event }\end{array}$ & $\begin{array}{c}\text { Other } \\
\text { observations }\end{array}$ \\
\hline 1 & 2 & 118 & 3 & 27.04 .15 & 2 & \\
\hline 2 & 2 & 118 & 1 & 27.05 .15 & 2 & \\
\hline 3 & 2 & 118 & 1 & 28.06 .15 & 4 & \\
\hline 4 & 2 & 118 & 1 & 16.07 .15 & 5 & \\
\hline 5 & 2 & 118 & 1 & 10.08 .15 & 5 & \\
\hline 6 & 2 & 118 & 2 & 11.09 .15 & 1 & \\
\hline 8 & 2 & 118 & 2 & 14.10 .15 & 2 & \\
\hline 9 & 2 & 118 & 2 & 21.10 .15 & 3 & \\
\hline 10 & 2 & 118 & 3 & 13.11 .15 & 1 & \\
\hline
\end{tabular}

Table 8. Phenological phenomena records - sample plot Kopaonik

\begin{tabular}{|c|c|c|c|c|c|c|c|}
\hline No. & Plot no. & $\begin{array}{c}\text { Tree } \\
\text { no. }\end{array}$ & Event & $\begin{array}{c}\text { Observation } \\
\text { date }\end{array}$ & $\begin{array}{c}\text { Registered } \\
\text { event }\end{array}$ & $\begin{array}{c}\text { Observation } \\
\text { method used }\end{array}$ & $\begin{array}{c}\text { Other } \\
\text { observations }\end{array}$ \\
\hline 1 & 2 & 75 & 3 & 27.04 .15 & 2 & 1 & Usnea barbata \\
\hline 2 & 2 & 76 & 3 & 27.04 .15 & 2 & 1 & Usnea barbata \\
\hline 3 & 2 & 78 & 3 & 27.04 .15 & 2 & 1 & Usnea barbata \\
\hline
\end{tabular}




\begin{tabular}{|c|c|c|c|c|c|c|c|}
\hline No. & Plot no. & $\begin{array}{l}\text { Tree } \\
\text { no. }\end{array}$ & Event & $\begin{array}{c}\text { Observation } \\
\text { date }\end{array}$ & $\begin{array}{c}\text { Registered } \\
\text { event }\end{array}$ & $\begin{array}{l}\text { Observation } \\
\text { method used }\end{array}$ & $\begin{array}{c}\text { Other } \\
\text { observations }\end{array}$ \\
\hline 4 & 2 & 79 & 3 & 27.04 .15 & 2 & 1 & Usnea barbata \\
\hline 5 & 2 & 80 & 3 & 27.04 .15 & 2 & 1 & Usnea barbata \\
\hline 6 & 2 & 85 & 3 & 27.04 .15 & 2 & 1 & Usnea barbata \\
\hline 7 & 2 & 86 & 3 & 27.04 .15 & 2 & 1 & Usnea barbata \\
\hline 8 & 2 & 87 & 5 & 27.04 .15 & 7 & 1 & Bark beetles \\
\hline 9 & 2 & 88 & 5 & 27.04 .15 & 7 & 1 & Bark beetles \\
\hline 10 & 2 & 98 & 3 & $\begin{array}{l}27.04 .15 \\
\end{array}$ & 2 & 1 & Usnea barbata \\
\hline 11 & 2 & 114 & 5 & 27.04 .15 & 7 & 1 & Bark beetles \\
\hline 12 & 2 & 118 & 3 & 27.04 .15 & 2 & 1 & Usnea barbata \\
\hline 13 & 2 & 120 & 3 & 27.04 .15 & 2 & 1 & Usnea barbata \\
\hline 14 & 2 & 121 & 3 & 27.04 .15 & 2 & 1 & Usnea barbata \\
\hline 15 & 2 & 124 & 3 & 27.04 .15 & 2 & 1 & Usnea barbata \\
\hline 1 & 2 & 75 & 1 & 27.05 .15 & 2 & 1 & Usnea barbata \\
\hline 2 & 2 & 76 & 1 & 27.05 .15 & 2 & 1 & Usnea barbata \\
\hline 3 & 2 & 78 & 1 & 27.05 .15 & 2 & 1 & Usnea barbata \\
\hline 4 & 2 & 79 & 1 & 27.05 .15 & 2 & 1 & Usnea barbata \\
\hline 5 & 2 & 80 & 1 & 27.05 .15 & 2 & 1 & Usnea barbata \\
\hline 6 & 2 & 85 & 1 & 27.05 .15 & 2 & 1 & Usnea barbata \\
\hline 7 & 2 & 86 & 1 & 27.05 .15 & 2 & 1 & Usnea barbata \\
\hline 8 & 2 & 87 & 5 & 27.05 .15 & 7 & 1 & Bark beetles \\
\hline 9 & 2 & 88 & 5 & 27.05 .15 & 7 & 1 & Bark beetles \\
\hline 10 & 2 & 98 & 1 & 27.05 .15 & 2 & 1 & Usnea barbata \\
\hline 11 & 2 & 114 & 5 & 27.05 .15 & 7 & 1 & Bark beetles \\
\hline 12 & 2 & 118 & 1 & 27.05 .15 & 2 & 1 & Usnea barbata \\
\hline 13 & 2 & 120 & 1 & 27.05 .15 & 2 & 1 & Usnea barbata \\
\hline 14 & 2 & 121 & 1 & 27.05 .15 & 2 & 1 & Usnea barbata \\
\hline 15 & 2 & 124 & 1 & 27.05 .15 & 2 & 1 & Usnea barbata \\
\hline 1 & 2 & 75 & 1 & 28.06 .15 & 4 & 1 & Usnea barbata \\
\hline 2 & 2 & 76 & 1 & 28.06 .15 & 4 & 1 & Usnea barbata \\
\hline 3 & 2 & 78 & 1 & 28.06 .15 & 4 & 1 & Usnea barbata \\
\hline 4 & 2 & 79 & 1 & 28.06 .15 & 4 & 1 & Usnea barbata \\
\hline 5 & 2 & 80 & 1 & 28.06 .15 & 4 & 1 & Usnea barbata \\
\hline 6 & 2 & 85 & 1 & 28.06 .15 & 4 & 1 & Usnea barbata \\
\hline 7 & 2 & 86 & 1 & 28.06 .15 & 4 & 1 & Usnea barbata \\
\hline 8 & 2 & 87 & 5 & 28.06 .15 & 7 & 1 & Bark beetles \\
\hline 9 & 2 & 88 & 5 & 28.06 .15 & 7 & 1 & Bark beetles \\
\hline 10 & 2 & 98 & 1 & 28.06 .15 & 4 & 1 & Usnea barbata \\
\hline 11 & 2 & 114 & 5 & 28.06 .15 & 7 & 1 & Bark beetles \\
\hline 12 & 2 & 118 & 1 & 28.06 .15 & 4 & 1 & Usnea barbata \\
\hline 13 & 2 & 120 & 1 & 28.06 .15 & 4 & 1 & Usnea barbata \\
\hline 14 & 2 & 121 & 1 & 28.06 .15 & 4 & 1 & Usnea barbata \\
\hline 15 & 2 & 124 & 1 & 28.06 .15 & 4 & 1 & Usnea barbata \\
\hline 1 & 2 & 75 & 1 & 16.07 .15 & 5 & 1 & Usnea barbata \\
\hline 2 & 2 & 76 & 1 & $\begin{array}{l}16.07 .15 \\
\end{array}$ & 5 & 1 & Usnea barbata \\
\hline 3 & 2 & 78 & 1 & 16.07 .15 & 5 & 1 & Usnea barbata \\
\hline 4 & 2 & 79 & 1 & 16.07 .15 & 5 & 1 & Usnea barbata \\
\hline 5 & 2 & 80 & 1 & 16.07 .15 & 5 & 1 & Usnea barbata \\
\hline 6 & 2 & 85 & 1 & 16.07 .15 & 5 & 1 & Usnea barbata \\
\hline 7 & 2 & 86 & 1 & 16.07 .15 & 5 & 1 & Usnea barbata \\
\hline 8 & 2 & 87 & 5 & 16.07 .15 & 7 & 1 & Bark beetles \\
\hline 9 & 2 & 88 & 5 & 16.07 .15 & 7 & 1 & Bark beetles \\
\hline 10 & 2 & 98 & 1 & 16.07 .15 & 5 & 1 & Usnea barbata \\
\hline 11 & 2 & 114 & 5 & 16.07 .15 & 7 & 1 & Bark beetles \\
\hline 12 & 2 & 118 & 1 & 16.07 .15 & 5 & 1 & Usnea barbata \\
\hline 13 & 2 & 120 & 1 & 16.07 .15 & 5 & 1 & Usnea barbata \\
\hline 14 & 2 & 121 & 1 & $\begin{array}{l}16.07 .15 \\
\end{array}$ & 5 & 1 & Usnea barbata \\
\hline 15 & 2 & 124 & 1 & 16.07 .15 & 5 & 1 & Usnea barbata \\
\hline
\end{tabular}




\begin{tabular}{|c|c|c|c|c|c|c|c|}
\hline No. & Plot no. & $\begin{array}{c}\text { Tree } \\
\text { no. }\end{array}$ & Event & $\begin{array}{c}\text { Observation } \\
\text { date }\end{array}$ & $\begin{array}{c}\text { Registered } \\
\text { event }\end{array}$ & $\begin{array}{l}\text { Observation } \\
\text { method used }\end{array}$ & $\begin{array}{c}\text { Other } \\
\text { observations }\end{array}$ \\
\hline 1 & 2 & 75 & 1 & 10.08 .15 & 5 & 1 & Usnea barbata \\
\hline 2 & 2 & 76 & 1 & 10.08 .15 & 5 & 1 & Usnea barbata \\
\hline 3 & 2 & 78 & 1 & 10.08 .15 & 5 & 1 & Usnea barbata \\
\hline 4 & 2 & 79 & 1 & 10.08 .15 & 5 & 1 & Usnea barbata \\
\hline 5 & 2 & 80 & 1 & 10.08 .15 & 5 & 1 & Usnea barbata \\
\hline 6 & 2 & 85 & 1 & 10.08 .15 & 5 & 1 & Usnea barbata \\
\hline 7 & 2 & 86 & 1 & 10.08 .15 & 5 & 1 & Usnea barbata \\
\hline 8 & 2 & 87 & 5 & 10.08 .15 & 7 & 1 & Bark beetles \\
\hline 9 & 2 & 88 & 5 & 10.08 .15 & 7 & 1 & Bark beetles \\
\hline 10 & 2 & 98 & 1 & 10.08 .15 & 5 & 1 & Usnea barbata \\
\hline 11 & 2 & 114 & 5 & 10.08 .15 & 7 & 1 & Bark beetles \\
\hline 12 & 2 & 118 & 1 & 10.08 .15 & 4 & 1 & Usnea barbata \\
\hline 13 & 2 & 120 & 1 & 10.08 .15 & 5 & 1 & Usnea barbata \\
\hline 14 & 2 & 121 & 1 & 10.08 .15 & 5 & 1 & Usnea barbata \\
\hline 15 & 2 & 124 & 1 & 10.08 .15 & 5 & 1 & Usnea barbata \\
\hline 1 & 2 & 75 & 2 & 11.09 .15 & 1 & 1 & Usnea barbata \\
\hline 2 & 2 & 76 & 2 & 11.09 .15 & 1 & 1 & Usnea barbata \\
\hline 3 & 2 & 78 & 2 & 11.09 .15 & 1 & 1 & Usnea barbata \\
\hline 4 & 2 & 79 & 2 & 11.09 .15 & 1 & 1 & Usnea barbata \\
\hline 5 & 2 & 80 & 2 & 11.09 .15 & 1 & 1 & Usnea barbata \\
\hline 6 & 2 & 85 & 2 & 11.09 .15 & 1 & 1 & Usnea barbata \\
\hline 7 & 2 & 86 & 2 & 11.09 .15 & 1 & 1 & Usnea barbata \\
\hline 8 & 2 & 87 & 5 & 11.09 .15 & 7 & 1 & Bark beetles \\
\hline 9 & 2 & 88 & 5 & 11.09 .15 & 7 & 1 & Bark beetles \\
\hline 10 & 2 & 98 & 2 & 11.09 .15 & 1 & 1 & Usnea barbata \\
\hline 11 & 2 & 114 & 5 & 11.09 .15 & 7 & 1 & Bark beetles \\
\hline 12 & 2 & 118 & 2 & 11.09 .15 & 1 & 1 & Usnea barbata \\
\hline 13 & 2 & 120 & 2 & 11.09 .15 & 1 & 1 & Usnea barbata \\
\hline 14 & 2 & 121 & 2 & 11.09 .15 & 1 & 1 & Usnea barbata \\
\hline 15 & 2 & 124 & 2 & 11.09 .15 & 1 & 1 & Usnea barbata \\
\hline 1 & 2 & 75 & 2 & 14.10 .15 & 2 & 1 & Usnea barbata \\
\hline 2 & 2 & 76 & 2 & 14.10 .15 & 2 & 1 & Usnea barbata \\
\hline 3 & 2 & 78 & 2 & 14.10 .15 & 2 & 1 & Usnea barbata \\
\hline 4 & 2 & 79 & 2 & 14.10 .15 & 2 & 1 & Usnea barbata \\
\hline 5 & 2 & 80 & 2 & 14.10 .15 & 2 & 1 & Usnea barbata \\
\hline 6 & 2 & 85 & 2 & 14.10 .15 & 2 & 1 & Usnea barbata \\
\hline 7 & 2 & 86 & 2 & 14.10 .15 & 2 & 1 & Usnea barbata \\
\hline 8 & 2 & 87 & 5 & 14.10 .15 & 7 & 1 & Bark beetles \\
\hline 9 & 2 & 88 & 5 & 14.10 .15 & 7 & 1 & Bark beetles \\
\hline 10 & 2 & 98 & 2 & 14.10 .15 & 2 & 1 & Usnea barbata \\
\hline 11 & 2 & 114 & 5 & 14.10 .15 & 7 & 1 & Bark beetles \\
\hline 12 & 2 & 118 & 2 & 14.10 .15 & 2 & 1 & Usnea barbata \\
\hline 13 & 2 & 120 & 2 & 14.10 .15 & 2 & 1 & Usnea barbata \\
\hline 14 & 2 & 121 & 2 & 14.10 .15 & 2 & 1 & Usnea barbata \\
\hline 15 & 2 & 124 & 2 & $\begin{array}{l}4.10 .15 \\
\end{array}$ & 2 & 1 & Usnea barbata \\
\hline 1 & 2 & 75 & 2 & 23.10 .15 & 3 & 1 & Usnea barbata \\
\hline 2 & 2 & 76 & 2 & 23.10 .15 & 3 & 1 & Usnea barbata \\
\hline 3 & 2 & 78 & 2 & 23.10 .15 & 3 & 1 & Usnea barbata \\
\hline 4 & 2 & 79 & 2 & 23.10 .15 & 3 & 1 & Usnea barbata \\
\hline 5 & 2 & 80 & 2 & 23.10 .15 & 3 & 1 & Usnea barbata \\
\hline 6 & 2 & 85 & 2 & 23.10 .15 & 3 & 1 & Usnea barbata \\
\hline 7 & 2 & 86 & 2 & 23.10 .15 & 3 & 1 & Usnea barbata \\
\hline 8 & 2 & 87 & 5 & 23.10 .15 & 7 & 1 & Bark beetles \\
\hline 9 & 2 & 88 & 5 & 23.10 .15 & 7 & 1 & Bark beetles \\
\hline 10 & 2 & 98 & 2 & 23.10 .15 & 3 & 1 & Usnea barbata \\
\hline 11 & 2 & 114 & 5 & 23.10 .15 & 7 & 1 & Bark beetles \\
\hline 12 & 2 & 118 & 2 & 23.10 .15 & 3 & 1 & Usnea barbata \\
\hline
\end{tabular}




\begin{tabular}{|c|c|c|c|c|c|c|c|}
\hline No. & Plot no. & $\begin{array}{c}\text { Tree } \\
\text { no. }\end{array}$ & Event & $\begin{array}{c}\text { Observation } \\
\text { date }\end{array}$ & $\begin{array}{c}\text { Registered } \\
\text { event }\end{array}$ & $\begin{array}{c}\text { Observation } \\
\text { method used }\end{array}$ & $\begin{array}{c}\text { Other } \\
\text { observations }\end{array}$ \\
\hline 13 & 2 & 120 & 2 & 23.10 .15 & 3 & 1 & Usnea barbata \\
\hline 14 & 2 & 121 & 2 & 23.10 .15 & 3 & 1 & Usnea barbata \\
\hline 15 & 2 & 124 & 2 & 23.10 .15 & 3 & 1 & Usnea barbata \\
\hline 1 & 2 & 75 & 3 & 13.11 .15 & 1 & 1 & Usnea barbata \\
\hline 2 & 2 & 76 & 3 & 13.11 .15 & 1 & 1 & Usnea barbata \\
\hline 3 & 2 & 78 & 3 & 13.11 .15 & 1 & 1 & Usnea barbata \\
\hline 4 & 2 & 79 & 3 & 13.11 .15 & 1 & 1 & Usnea barbata \\
\hline 5 & 2 & 80 & 3 & 13.11 .15 & 1 & 1 & Usnea barbata \\
\hline 6 & 2 & 85 & 3 & 13.11 .15 & 1 & 1 & Usnea barbata \\
\hline 7 & 2 & 86 & 3 & 13.11 .15 & 1 & 1 & Usnea barbata \\
\hline 8 & 2 & 87 & 5 & 13.11 .15 & 7 & 1 & Bark beetles \\
\hline 9 & 2 & 88 & 5 & 13.11 .15 & 7 & 1 & Bark beetles \\
\hline 10 & 2 & 98 & 3 & 13.11 .15 & 1 & 1 & Usnea barbata \\
\hline 11 & 2 & 114 & 5 & 13.11 .15 & 7 & 1 & Bark beetles \\
\hline 12 & 2 & 118 & 3 & 13.11 .15 & 1 & 1 & Usnea barbata \\
\hline 13 & 2 & 120 & 3 & 13.11 .15 & 1 & 1 & Usnea barbata \\
\hline 14 & 2 & 121 & 3 & 13.11 .15 & 1 & 1 & Usnea barbata \\
\hline 15 & 2 & 124 & 3 & 13.11 .15 & 1 & 1 & Usnea barbata \\
\hline
\end{tabular}

During the first visits to the test sample plot Kopaonik in 2015 (on January 28 and March 19) phenophase was not assessed as the trees were covered with snow. Examination of trees conducted on April 27, 2015 revealed needle fallout at the $1-33 \%$ level. The following examination of trees (on May 27) revealed growth of the current year's needles at the 1-33\% level, while new needle growth reached $66-99 \%$ on June 28 . The same situation was recorded upon examination on August 10. Discoloration was perceived on September 11 to the extent below 1\%, while on October 14 it reached 33\%. On October 23, discoloration level was in the 33-66\% range. Needle fallout below $1 \%$ was determined upon examination on November 13, 2015. Upon each examination performed in 2015, bark beetle damages were observed in trees no: 87,88 and 114 .

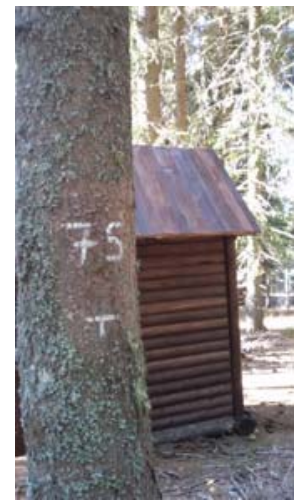

Kopaonik: Phenolog. trunk no.75; $13 / 11 / 2015$

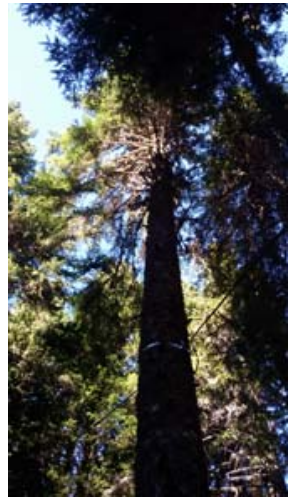

Kopaonik: Phenolog. Crown no.75; 13/11/2015

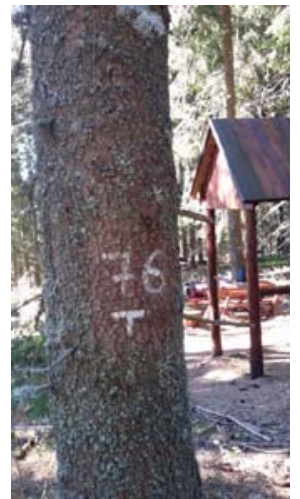

Kopaonik: Phenolog. trunk no.76; $13 / 11 / 2015$

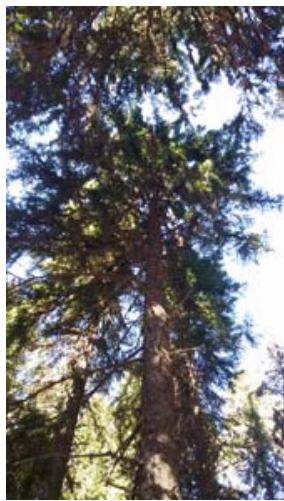

Kopaonik: Phenolog. Crown no.76; 13/11/2015 


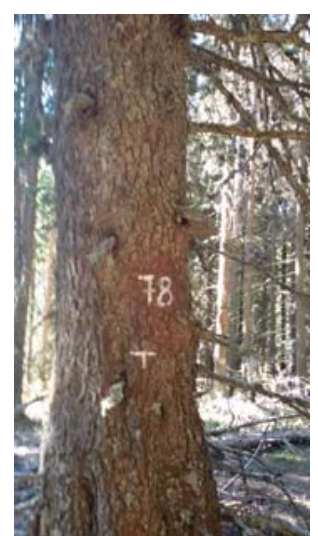

Kopaonik: Phenolog. trunk no.78; 13/11/2015

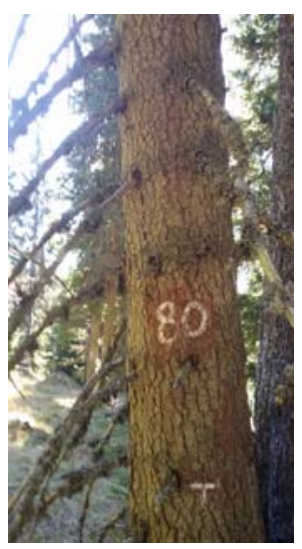

Kopaonik: Phenolog. trunk no.80; $13 / 11 / 2015$

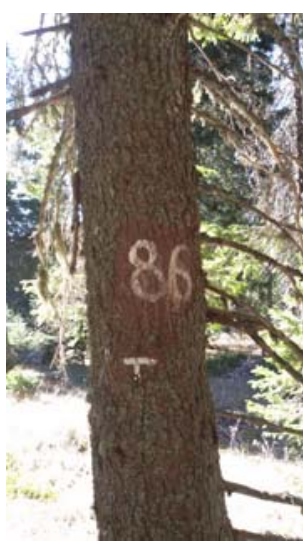

Kopaonik: Phenolog. trunk no.86; $13 / 11 / 2015$

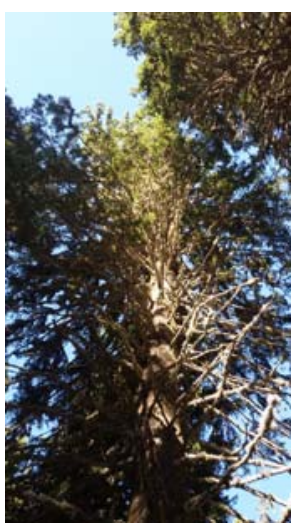

Kopaonik: Phenolog. Crown no.78; $13 / 11 / 2015$

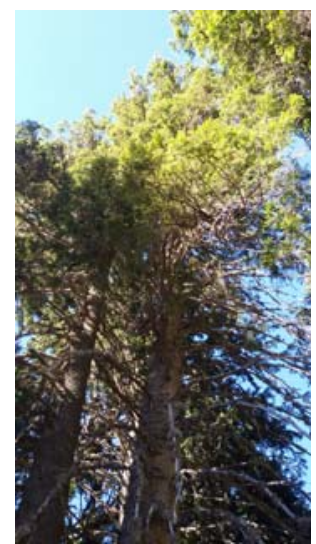

Kopaonik: Phenolog. Crown no.80; $13 / 11 / 2015$

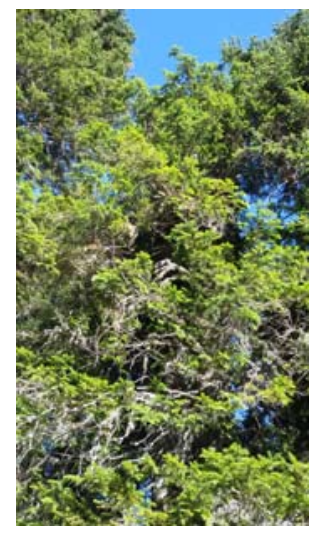

Kopaonik: Phenolog. Crown no.86; $13 / 11 / 2015$

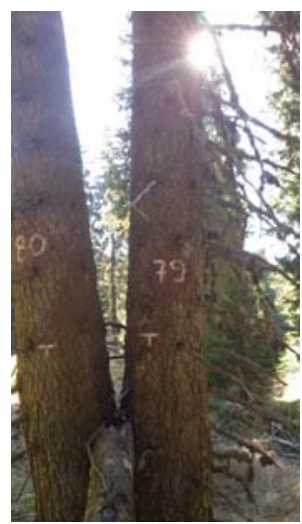

Kopaonik: Phenolog. trunk no.79; $13 / 11 / 2015$

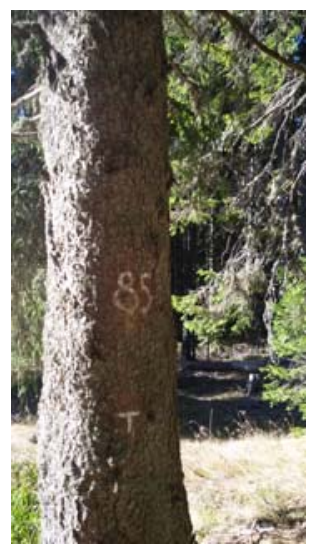

Kopaonik: Phenolog. trunk no.85; 13/11/2015

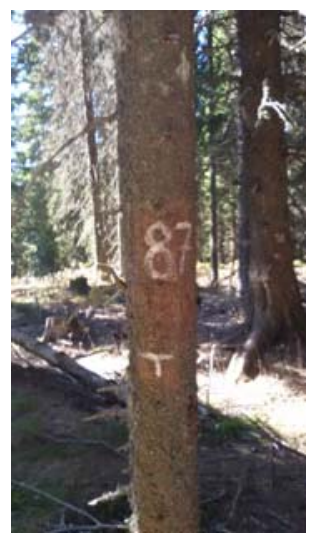

Kopaonik: Phenolog. trunk no.87; 13/11/2015

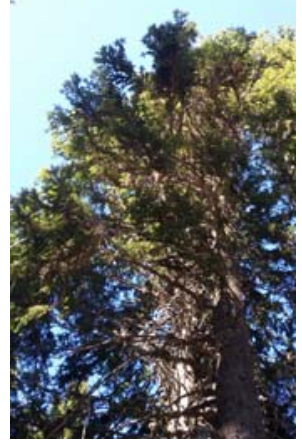

Kopaonik: Phenolog. Crown no.79; $13 / 11 / 2015$

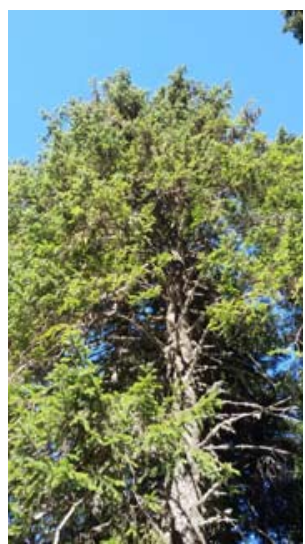

Kopaonik: Phenolog.

Crown no.85;

$13 / 11 / 2015$

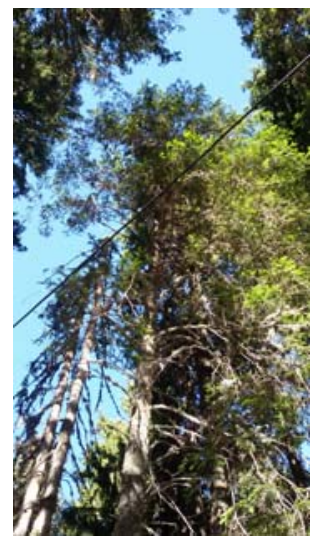

Kopaonik: Phenolog. Crown no.87; $13 / 11 / 2015$ 


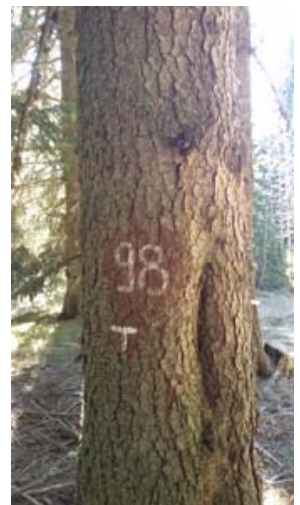

Kopaonik: Phenolog. trunk no.98;

13/11/2015

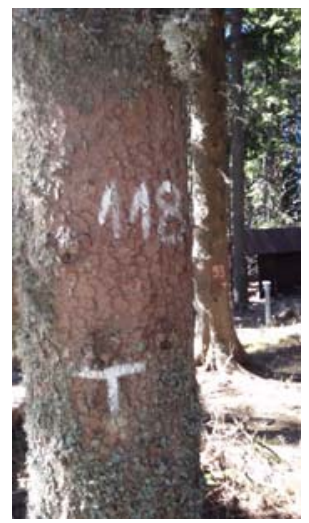

Kopaonik: Phenolog. trunk no.118;

$13 / 11 / 2015$

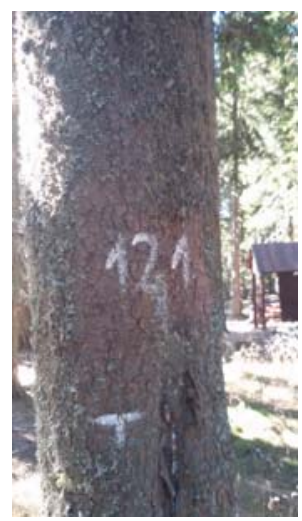

Kopaonik: Phenolog. trunk no.121; $13 / 11 / 2015$

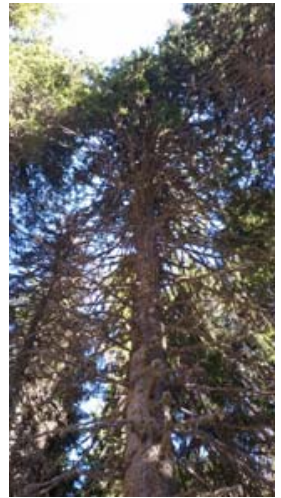

Kopaonik: Phenolog. Crown no.98; $13 / 11 / 2015$

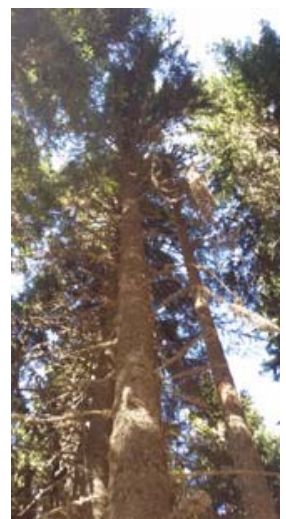

Kopaonik: Phenolog. Crown no.118; $13 / 11 / 2015$

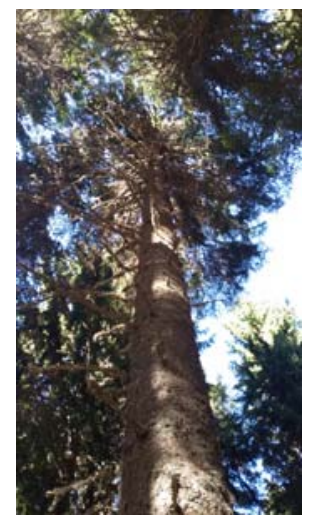

Kopaonik: Phenolog. Crown no.121; $13 / 11 / 2015$

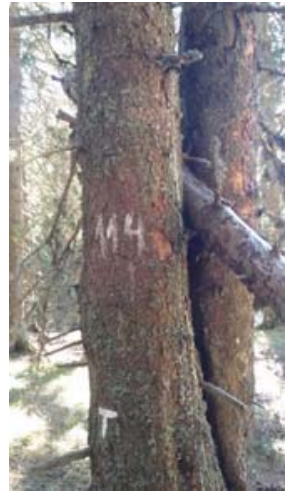

Kopaonik: Phenolog. trunk no.114; $13 / 11 / 2015$

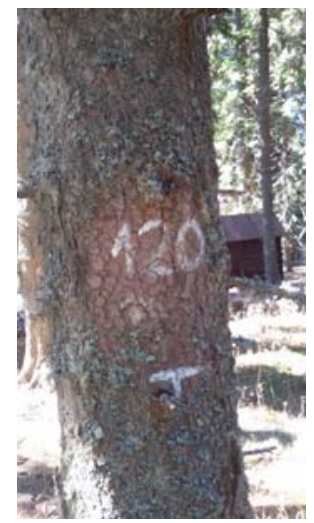

Kopaonik: Phenolog. trunk no.120; $13 / 11 / 2015$

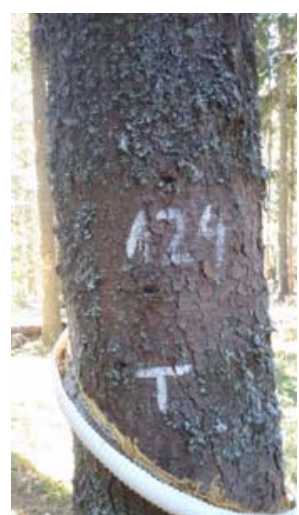

Kopaonik: Phenolog. trunk no.124; $13 / 11 / 2015$

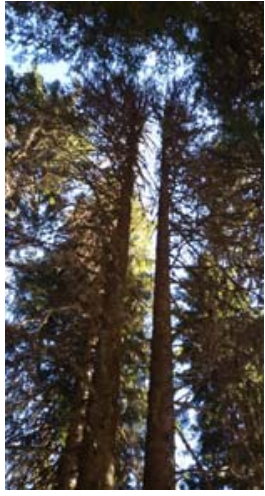

Kopaonik: Phenolog. Crown no.114; $13 / 11 / 2015$

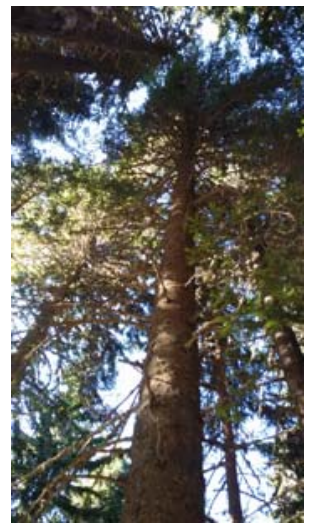

Kopaonik: Phenolog. Crown no.120; $13 / 11 / 2015$

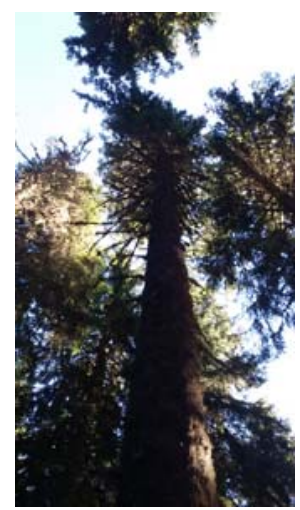

Kopaonik: Phenolog. Crown no.124; $13 / 11 / 2015$

Figures 9-36. Trees selected for phenological observations at sample plot Kopaonik, November 13, 2015 (original photo of the Author) 
Installation of solar collector at Level II sample plot Kopaonik enabled phenology monitoring using the most contemporary approach. In October 2015 a camera was placed on tree no. 86 for 24-hour recording of all events on the tree selected for phenological observations. The recorded material (on a film) is stored in the recorder placed in the shed for equipment and instruments. To avoid interruptions in recording, two recorders were obtained. Once a month a recorder with the recorded material was delivered to the laboratory of the Forestry Institute where the recordings were processed and the recorded with the empty memory was placed to record events during the following month.

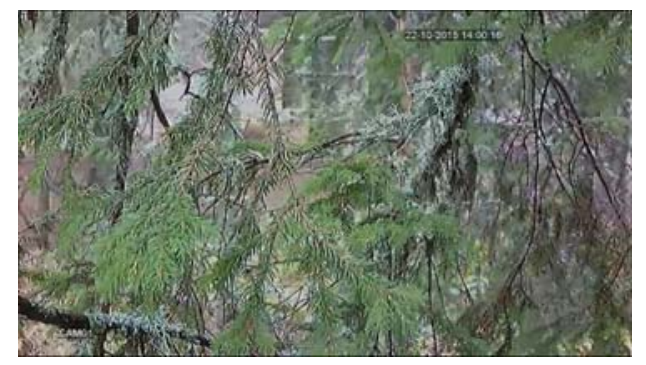

Figure 37. Camera recording on Oct 22, 2015 at 2.00 p.m.

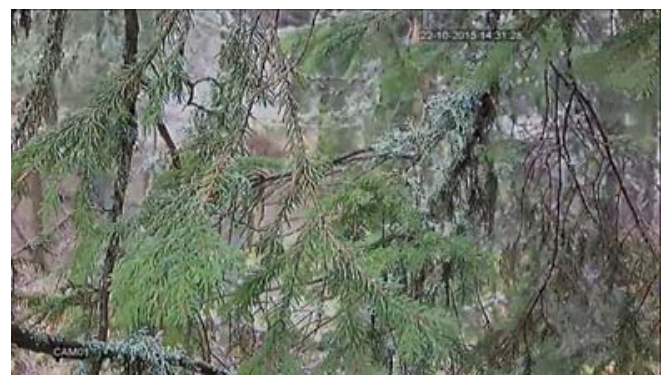

Figure 39. Camera recording on Oct 22, 2015 at 2.31 p.m.

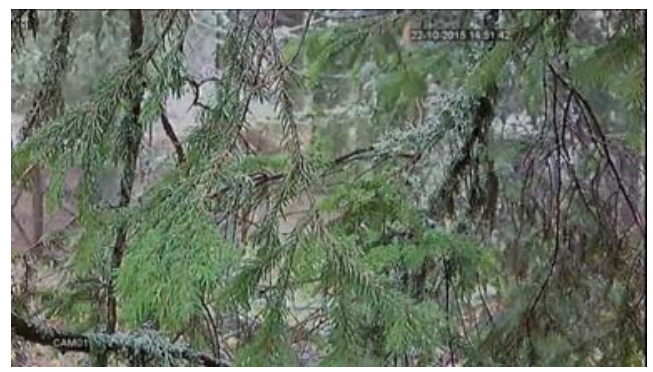

Figure 41. Camera recording on Oct 22, 2015 at 2.51 p.m.

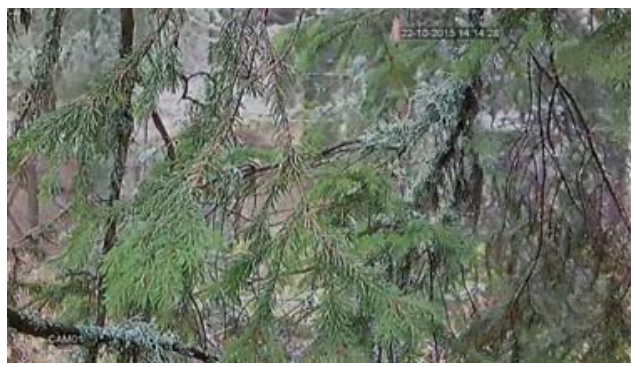

Figure 38. Camera recording on Oct 22, 2015 at 2.14 p.m.

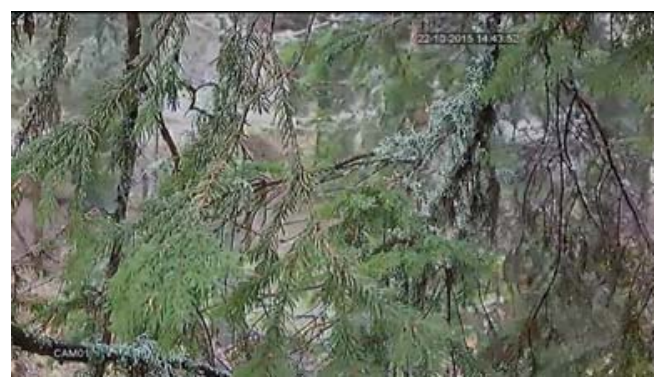

Figure 40. Camera recording on Oct 22, 2015 at 2.43 p.m.

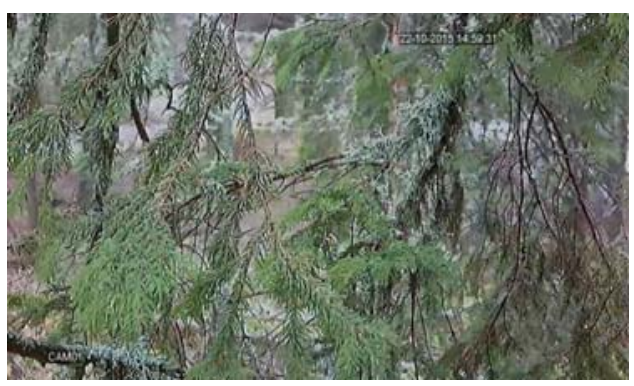

Figure 42. Camera recording on Oct 22, 2015 at 2.59 p.m. 


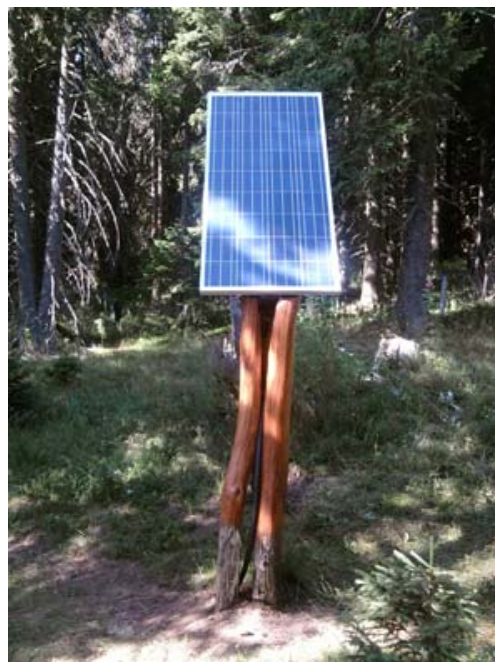

Figure 43. Solar panel for electricity generation Level II sample plot Kopaonik (original photo of the Author)

\section{DISCUSSION}

Continuous monitoring of forest health condition at sample plots applying scientifically confirmed methods vouches for active and ongoing supervision of the forest ecosystem conditions. Monitoring results are used as integral parts of legislative documents and international conventions whose objective is maintenance and improvement of the existing conditions. Public availability of and free access to information related to the condition of forests and forestry and their timely communication are a basis for adequate decision making on and understanding of forestry issues by the public. Introduction of the system for monitoring the forest health condition and vitality in accordance with UN/ECE and EU methodology enables increased contribution of the forestry industry to the overall economic and social development of the Republic of Serbia.

Forest drying is a result of adverse complex effects of several factors, both abiotic and biotic in nature, which may act simultaneously or consecutively. The final outcome of such changes does not always imply that the primary agent is the sole cause of the consequences or that the final agent in succession is the most significant (Halmschlager, E., 1998).

A forest ecosystem, as an extremely complex entity, is characterized by different parameters subject to constant variation due continuous and inseparable effects of abiotic and biotic factors.

Challenges and objectives of a research approach such as this involve several years of analyses in order to be able to draw conclusion on the phenomenon of forest drying across Europe and define more clearly the "cause and effect" system for all monitored phenomena.

Assessment criteria applied in intensive monitoring are all compatible and defined in such a manner that upon recording and statistical analysis, the obtained data are easily compared analytically and logically, providing the basis for a variety of comparative studies. By perceiving similarities and dissimilarities, assumptions on the primary causes of the disturbed natural equilibrium in the forest 
biocenoses are rejected or accepted, further progress of the changes is anticipated and further degradation of forests as invaluable natural entities is prevented strategically, from the aspects of multiple applied forestry disciplines.

\section{CONCLUSION}

Air pollution impact assessment and monitoring of its effects on the forest ecosystems in the territory of the Republic of Serbia without AP Vojvodina in 2015 (Level I) and intensive monitoring of forest vitality (Level II) projects at locations within the remit of Public Company "Kopaonik", Management Unit "Samokovska Reka", Public Company "Srbijašume", Forest Estate "Užice", Management Unit "Mokra Gora - Panjak" and Forest Estate "Timočke Šume" Boljevac, Management Unit "Crni Vrh", are aimed at creation and advancement of both national and panEuropean monitoring system over forests and forest ecosystems. Continuous monitoring is a basis for preparation of the relevant information on the condition of forest ecosystems to which we are obligated under the National Forest Action Programme and international environment protection conventions signed. Crown condition assessment involved determining defoliation extent as an indicator of the assimilation organ drying, tree drying and removal, tree status, crown shade, crown visibility and foliage transparency.

Injuries were also detected in selected trees. For each tree where injury/damage was identified, location, symptom, cause and intensity of injury/damage are stated. There is a visible trend of mild drying in trees observed since 2012, attributed primarily to entomological causes (Stefanović, T., et al 2012).

Noticeable presence of bark beetles was identified at sample plots. Bark beetles are secondary pests infesting already diseased and physiologically weakened trees. However, unless the infested trees are removed, bark beetles spread cyclically to other trees as well. Within several sample plots (outside of the trees examined in detail) complete drying of trees was observed with stripped bark and severe bark beetle infestation. Therefore the percentage with moderate defoliation in Europe may be described as reduced as compared to 2014 ("The Condition of Forests in Europe, 2014 Executive Report"). In 2015 severe defoliation was not recorded in any of the trees - no deterioration was identified.

ACKNOWLEDGEMENTS: The study was carried out within the Projects:

1. Assessment and monitoring of the impact of air pollution and its effects on the forest ecosystems in the Republic of Serbia without AP Vojvodina in 2015 (Level 1) and implementing intensive monitoring (Level 2) at locations which are located in the area of PE "Kopaonik" Management Unit "Samokovska Reka", Srbijašume, PE "Uzice" Management Unit "Mokra Gora - Panjak", PE “Timocke Sume” Boljevac, Management Unit "Crni Vrh", financed by the Directorate of Forests, Ministry for Agriculture and Environment Protection of the Republic of Serbia, Contract No: 401-00-001085/2015-10, 18. 05. 2015. Year;

and 
2. Project TP-31070: "The Development of Technological Methods in Forestry in order to Attain Optimal Forest Cover", financed by the Ministry of Education and Science of the Republic of Serbia.

\section{REFERENCES:}

***** (2014): The Condition of Forests in Europe, 2014 Executive Report. United Economic Commission for Europe. Federal Research Centre for Forestry and Forest Products (BFH), Hamburg

Chira, D., F. Chira, 1998: Beech problem in Romania. From: Proceedings of a workshop of IUFRO working party 7. 02. 06, Disease / environment interaction in forest decline. 23-29. Vienna

Glavendekic M., Medarevic M. (2010): Insect defoliators and their influence on oak forests in the Djerdap National Park, Serbia, Arc. Biol. Sci. Belgrade,62(4), 1137-1141, 2010

Halmschlager, E., 1998: The possible role of Armillaria spp. and Phytophthora spp. in the oak decline complex. From: Proceedings of a workshop of IUFRO working party, 07. 02. 2006, Disease / environment interaction in forest" pp. 49-56., Vienna.

Jancic, G. (2013): Causes of dieback and rehabilitation measures. Review "Sume" PE "Srbijasume", No.120 pp.10-11, Belgrade

***** (2010) ICP Forests Manual, Manual on methods and criteria for harmonized Sampling on forests - Parts I. II. IX. V. VII. VIII. IX. XVII; ISBN 978-3-926301-01-1. Johann Heinrich von Thunen - Institute. Institute for World Forestry. PCC of ICP Forests. Hamburg. Germany. Edited in 2010

Marković, M., Rajković, S. and Nevenić, R., (2014) The most frequent agents of damages of trees at the sample plots in Serbia, Sustainable Forestry Collection 69-70, 2014, pp. 8593.

Mougou, A.; Dutech, C.; Desprez-Loustau, M. -L. (2008). "New insights into the identity and origin of the causal agent of oak powdery mildew in Europe". Forest Pathology 38 (4): 275. doi:10.1111/j.1439-0329.2008.00544.x

Kinver, M. (2010). "Oak disease 'threatens landscape"'. BBC News. Retrieved 29 April 2010.

Nevenic, R. at.al. (2006): Forest condition monitoring in the Republic of Serbia. Annual ICP forests Report 2006.

LEVEL I. Forest Condition Monitoring in the Republic of Serbia. Annual Report ICP Forests 2006. Level I. Institute of Forestry, Belgrade. p.p. 21-23.ISSN 1452/8576

Nevenic, R, 2008: GIS as a Tool in Forest monitoring in Serbia in a frame of ICP Forest Monitoring Programme. Symposium of Computer and Informatics Technologies YU INFO 2008. Kopaonik, Serbia. Proceedings, p.p. 284-287. ISBN 978-85525-03-02.

Nevenić, R., Tabaković-Tošić, M., Rakonjac, Lj. (2009): Some Indicators of Forest Vitality in the Republic of Serbia, Monograph, Institute of Forestry, Belgrade.

Nevenić, R., Rakonjac, Lj., Orlović, S. (2011): Assessment and monitoring of the impact of air pollution and its effects on the forest ecosystems in the territory of the Republic of Serbia - Forest Condition Monitoring, Level I and Level II, Monograph, Institute of Forestry, Belgrade. 
Nevenić, R., Tabaković-Tošić, M., Rakonkac, Lj. (2009): Some Indicators of Forest Vitality in the Republic of Serbia, Monograph, Institute of Forestry, Belgrade.

Češljar ,G. Nevenić R., Bilibajkić, S., Stefanović, T.,Gagić Serdar, R., Poduska Z., Đorđević I. (2013): Viability of trees on Bio-Indicator plots Level 1 in Republic of Serbia in 2013, Sustainable Forestry Collection 67-68, 2013, pp 69-78

Stefanović, T., Poduska Z., Đorđević I., Nevenić, R., Bilibajkić, S., Marković, N. (2012): Research of defoliation on ICP Forests Sample Plots in the Republic of Serbia. International scientific Conference, Forests in the Future-Sustainable Use, Risks, and Challenges. Institute of forestry, Belgrade 4-5 October, 2012, pp 911-915.

Tabaković-Tošić M. et al (2014): Diagnostic Report on Harmful organisms and Protection of Forest Plant Health in the Territory of the Republic of Serbia without AP Vojvodina in 2014. Institute of Forestry, http://www.forest.org.rs/pdf/ Report-IDPS-2014.2014

\section{AIR POLLUTION IMPACT ASSESSMENT AND MONITORING, ITS EFFECTS ON THE FOREST ECOSYSTEMS IN THE TERRITORY OF THE REPUBLIC OF SERBIA IN 2015}

Renata GAGIĆ SERDAR, Tomislav STEFANOVIĆ, Goran ČEŠLJAR, Svetlana BILIBAJKIĆ, Radovan NEVENIĆ, Ilija ĐORĐEVIĆ, Zoran PODUŠKA,

\section{Summary}

For many years research in the field of monitoring the vitality of forests has been carried out in our country according to the international guidelines and the same methodology is applied in other European countries.

The National Focal Centre for Forest Monitoring in the Republic of Serbia, within the Institute of Forestry of the Republic of Serbia is actively participating in the ICP Forests international program, with a tendency of improving their work activities alignment with modern international approaches. The results of work and research indicate the vitality of forests in terms of the first occurrence of defoliation, representing primarily determined regularity; especially those that are severe stress agents in forest trees. Impairment and injuries were recognized and their causes determined in 2015. Fluctuations in the state of crowns of trees were monitored through several parameters, and the most significant findings summarized and presented as a major and important indicators of health and fitness of forests in Serbia in 2015 in particular. 


\title{
ПРОЦЕНА И ПРАЋЕЊЕ УТИЦАЈА ЗАГАЪЕЊА ВАЗДУХА И ЕФЕКАТА ИСТОГ У ШУМСКИМ ЕКОСИСТЕМИМА НА ТЕРИТОРИЈИ РЕПУБЛИКЕ СРБИЈЕ У 2015 ГОДИНИ
}

\author{
Рената ГАГИЋ СЕРДАР, Томислав СТЕФАНОВИЋ, Горан ЧЕШЉАР, Светлана \\ БИЛИБАЈКИЋ, Радован НЕВЕНИЋ, Илија ЂОРЪЕВИЋ, Зоран ПОДУШКА
}

\begin{abstract}
Резиме
Дугогодишња истраживања, у домену праћења виталности шума, се спроводе према међународном упутству у нашој земьи а, по истој методологији раде и остале државе Европе.

Национални Фоцал Центар за мониторинг шума у Републищи Србији, у оквиру Института за шумарство Републике Србије је активно учествује у међународном програму ICP Forest, са тенденщијама унапређења својих радних активности и њиховог усклађивања са модерним страним приступима. Резултати рада и истраживања указују на виталност шума са аспекта прво појаве дефолијаџије, представљајући прво.одређене правилности; посебно оне који су озбиљни агенси стреса код шумског дрвећа. Оштећења су препозната и детерминисан је юихов узрок у 2015 години. Флуктуащије у стану круна дрвећа праћене су кроз неколико параметара а најважнији налази сумарно су представљене као главни и значајне показатеље здравствено-кондиционог стања шума Србије у конкретно за 2015. годину
\end{abstract}

